JIFI (JURNAL ILMIAH FARMASI IMELDA)

Vol.5, No.1, September 2021, pp. 26-34

ISSN: 2597-7164 (Online), 2655-3147 (Print)

https://jurnal.uimedan.ac.id/index.php/JURNALFARMASI

\title{
EFEK EKSTRAK TANAMAN ASHITABA PADA KADAR SERUM ALKALIN FOSFATASE (ALP) PADA TIKUS YANG TERPAPAR LUKA BAKAR
}

\author{
Andrew Johan ${ }^{1}$, Kusmiyati Tjahjono ${ }^{2}$, Wenda Yoanda ${ }^{3}$, Dwi Ngestiningsih ${ }^{4}$, Lusiana Batubara ${ }^{5}$ \\ 1,2,3,4,5 Department of Biology and Biochemistry, Faculty of Medicine, Diponegoro University, Semarang, \\ Indonesia
}

\begin{tabular}{l}
\hline Article Info \\
\hline Article history: \\
Received Sep 27, 2021 \\
Revised Sep 29, 2021 \\
Accepted Sep 30, 2021 \\
\hline
\end{tabular}

Keywords:

Ashitaba Extract

Serum Alkaline Phosphatase

Burn Injury

\begin{abstract}
Serum alkaline phosphatase (ALP) levels increases in burn tissue damage. The extract of Ashitaba, are expected to reduce serum ALP levels and enhance the process of wound healing. This study aims to prove that administration of oral Ashitaba extract can reduce serum ALP levels in rats exposed to burn injury. This study uses experimental post-test only with control group design. A total number of 20 male Sprague dawley rats as samples. All samples were treated with 2 nd degree burn wound and divided into 2 groups, treatment group (Ashitaba extract $300 \mathrm{mg} / \mathrm{KgBW}$ ) and control group. Blood serum were analyzed for ALP levels on the 2nd, 8th and 14th days. Kinetic-IFCC method was used to find serum ALP levels. Data was analyzed using Mann-Whitney Test, paired T-test amd independence T-test. Scalded wound size was measured macroscopically over the course of 21 days to find contracture rate. In conclusion, Ashitaba extract is not proven to significantly reduce the serum ALP levels, increase contracture rate and enhance burn wound healing process. However, there was slight increase (14\%) in contracture rate in treatment group as compared to control group. In addition, there was a lower ALP levels (30\%) in treatment group as compared to control group in day 8 .
\end{abstract}

This is an open access article under the CC BY-SAlicense.

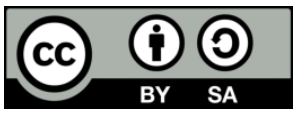

\section{Corresponding Author:}

Andrew Johan,

Department of Biology and Biochemistry,

Diponegoro University,

Jl. Jl Prof Sudharto, SH Tembalang Semarang 50275, Jawa Tengah-Indonesia.

Email: andrewjohan@fk.undip.ac.id

\section{INTRODUCTION}

Luka bakar didefinisikan sebagai kerusakan pada kulit dan/atau lapisan jaringan dalam yang disebabkan oleh api, cairan panas, gigitan beku, listrik, radiasi, laser dan bahan kimia. Morbiditas dan mortalitas luka bakar cukup tinggi. Menurut Organisasi Kesehatan Dunia (WHO), 90\% dari insiden luka bakar terjadi pada individu dengan status sosial ekonomi rendah di negara berkembang dimana infrastruktur dibangun dengan buruk. Angka kejadian luka bakar tertinggi pada wanita di Asia Tenggara dan 27\% pasien luka bakar di seluruh dunia berakhir dengan kematian. Data dari studi epidemiologi yang dilakukan di Rumah Sakit Cipto Mangunkusumo 
(RSCM) antara tahun 2012 dan 2016 menunjukkan bahwa penyebab utama luka bakar pada orang dewasa adalah api $(53,1 \%)$, diikuti oleh air panas $(19,1 \%)$, listrik (14\%), kontak (5\%) dan terakhir bahan kimia (3\%) [1]. Penyebab utama luka bakar pada anak adalah air panas (52\%), diikuti oleh api $(26 \%)$, kontak (15\%), listrik (6\%) dan terakhir bahan kimia (1\%). Sebuah artikel oleh GarciaEspinoza et al pada tahun 2017 menyebutkan bahwa penyebab luka bakar yang paling sering adalah karena cairan panas [2]. Derajat luka bakar dapat diklasifikasikan menjadi 3 kelompok. Luka bakar derajat satu hanya mengenai lapisan epitel dengan gejala seperti kemerahan tanpa vesikel. Luka bakar tingkat dua mempengaruhi epidermis dan dermis sedangkan luka bakar tingkat ketiga melibatkan seluruh lapisan kulit [3]. Terdapat tiga mekanisme utama dalam patofisiologi luka bakar yang meliputi trombosis akibat kerusakan pembuluh darah, peningkatan mediator inflamasi dan faktor proapoptosis. Akibatnya, terjadi peningkatan mediator inflamasi seperti makrofag, sitokin, dan interleukin [4] [5]. Elemen proinflamasi, seperti spesies oksigen reaktif (ROS) dan spesies nitrogen reaktif (RNS), juga diproduksi pada luka bakar. Selain itu, isoenzim, alkalin fosfatase (ALP), yang biasanya hanya ditemukan pada organ tertentu, ditemukan meningkat pada kondisi patologis seperti kerusakan jaringan terutama pada inflamasi dan granulasi [6] [7].

Angelica keiskei koidzumi atau yang juga dikenal sebagai Ashitaba merupakan salah satu jenis tanaman herbal yang berasal dari Jepang yang telah dibudidaya di Indonesia. Ramuan ini terkenal di Asia sebagai obat alami yang efektif untuk berbagai penyakit seperti flu, hepatitis, radang sendi, masalah pencernaan, demam dan infeksi mikroba [8]. Ashitaba mengandung berbagai komponen bioaktif yang bermanfaat dimana terdapat tiga senyawa bioaktif utama yang meliputi prenylated chalcones, linier coumarine dan sudut, dan flavanon [9]. Senyawa ini ditemukan memiliki unsur sitotoksik, antidiabetik, antiobesitas, antioksidan, antiinflamasi, antitrombotik, antihipertensi dan antimikroba. Chalcone xanthoangelol dan 4-hydroxyderricin, komponen bioaktif utama Ashitaba terbukti dapat meningkatkan proliferasi dan migrasi sel endotel serta mempercepat proses penyembuhan luka [10]. Oleh karena itu, dengan banyak elemen bermanfaat seperti antiinflamasi, antioksidan dan antimikroba, Ashitaba memiliki potensi tinggi dalam mengobati luka bakar.

\title{
2. RESEARCH METHOD
}

Penelitian ini terdiri dari 2 tahap utama: 1. Uji coba hewan yang dilakukan di Laboratorium Hewan Fakultas Kedokteran Universitas Diponegoro, dan 2. Analisis serum darah yang dilakukan di Laboratorium Klinik Permata, Semarang. Prosedur percobaan telah disetujui oleh Komisi Etik Penelitian Fakultas Kedokteran Universitas Diponegoro Semarang No.102/EC/H/KEPK/FKUNDIP/VII/2019.

\begin{abstract}
Alat dan Bahan
Bahan yang digunakan dalam penelitian ini antara lain serbuk Ashitaba (Angelica keiskei koidzumi) siap pakai yang telah diteliti dan dikembangkan oleh Osaka-Pharmaceutical University dan disetujui oleh Badan Pengawas Obat dan Makanan Indonesia. Sebanyak 20 ekor tikus jantan Sprague Dawley digunakan sebagai subjek percobaan. Tikus-tikus tersebut berumur 10-12 minggu, dengan bobot badan antara 106-149 gram.
\end{abstract}

\section{Subjek Penelitian}

Dua puluh ekor tikus jantan Sprague Dawley dibagi dan ditempatkan dalam tiga kandang. Selama percobaan, siklus terang/gelap 12 jam yang terkontrol, suhu kamar $29^{\circ} \mathrm{C}$ dan kelembaban relatif $60 \%$ dipertahankan. Untuk tujuan aklimatisasi, tikus dibiarkan beradaptasi 1 minggu sebelum percobaan dimana mereka diberi akses cukup terhadap diet pelet dan air dalam botol. Satu hari sebelum proses perlakuan luka bakar, seluruh bagian punggung tikus dicukur untuk mendapatkan area yang tidak berbulu seluas $5 \mathrm{~cm} \times 5 \mathrm{~cm}$. Kemudian tikus dibius dengan menyuntikkan ketamin $0,1 \mathrm{ml} / 100 \mathrm{mg}$ secara intraperitoneal (i.p.). Setelah 5 menit anestesi, area yang tidak berbulu disiram air panas dengan menggunakan corong mulut berukuran $5 \mathrm{~cm}$ x $5 \mathrm{~cm}$ selama 15 detik. Kemudian, tikus diacak menjadi 2 kelompok yang sama terdiri dari sepuluh ekor yang meliputi kelompok kontrol (10 tikus diberi pakan standar tanpa ekstrak tanaman Ashitaba) dan kelompok perlakuan (10 tikus diberi pakan standar dan ekstrak tanaman Ashitaba dosis 
$300 \mathrm{mg} / \mathrm{kgBB}$ ) [11]. Setiap hari, daerah luka bakar akibat tersiram air panas dibilas dengan larutan natrium klorida 0,9\%. Ekstrak tanaman Ashitaba dosis $300 \mathrm{mg} / \mathrm{kgBB}$ diberikan secara oral setiap 2 hari selama 21 hari pengamatan.

\section{Pengukuran Kadar Alkalin Fosfatase (ALP)}

Untuk mengetahui kadar ALP, digunakan sampel serum darah retroorbital. Darah diambil tiga kali melalui retroorbital pada hari ke-2, 8 dan 14 setelah terpapar air mendidih. Darah retroorbital kemudian disentrifugasi selama 15 menit dengan kecepatan $1500 \mathrm{rpm}$. Metode KineticIFCC (tanpa pyridoxal-5-phosphate) [12] digunakan dalam analisis kadar ALP. Prinsip analisis ini adalah menentukan aktivitas kinetik ALP dengan mengukur P-nitrofenol menggunakan spektrofotometer.

Campuran reagen pada metode ini dihomogenkan pada suhu $37^{\circ} \mathrm{C}$ selama 30 detik. Tingkat absorbansi diukur pada panjang gelombang 400-420 nm menggunakan aquadest sebagai blanko. Tingkat absorbansi kemudian diukur kembali pada menit pertama, kedua dan ketiga dan dihitung kenaikan rata-rata absorbansi per menit. Aktivitas ALP kemudian dapat ditemukan dengan menggunakan persamaan berikut: Rata-rata peningkatan Absorbansi per menit x $3298=$ Aktivitas $\operatorname{ALP}(\mathrm{U} / \mathrm{I})$

\section{Evaluasi Proses Penyembuhan Luka Bakar}

Setiap hari, luka bakar didokumentasikan dan dievaluasi pada hari ke-1, 5, 8, 12, 15, 18 dan 21. Luka bakar dievaluasi berdasarkan parameter berikut: warna dasar luka, keluarnya cairan, kekencangan kulit dan adanya edema. Diameter luka diukur untuk tujuan menghitung laju kontraktur yang mengikuti rumus berikut [13]:

$$
\text { Laju kontraktur luka }=\frac{\text { Ukuran luka pada hari tertentu }}{\text { Ukuran luka pada hari perlakuan luka bakar }} \times 100 \%
$$

\section{RESULTS AND ANALYSIS}

\section{Tingkat Alkaline Fosfatase}

Pada penelitian ini, rata-rata kadar serum ALP pada kelompok kontrol pada hari ke-2 adalah 511 IU L-1 sedangkan rata-rata kadar ALP serum pada kelompok perlakuan pada hari ke-2 adalah 871 IU. Pada hari ke-8, rata-rata kadar ALP serum pada kelompok kontrol adalah 809 sedangkan pada kelompok perlakuan adalah 612. Rata-rata kadar serum ALP pada kelompok kontrol pada hari ke-14 adalah 894 sedangkan pada kelompok perlakuan adalah 890.

Tabel 1. Kadar Serum ALP Pada Kelompok Kontrol Dan Perlakuan Pada Hari Ke 2, 8 dan 14

\begin{tabular}{cccc}
\hline \multicolumn{2}{c}{ Kelompok } & N & Mean \pm SD (U/I) \\
\hline Hari ke-2 & Kontrol & 6 & $511,00 \pm 341,92$ \\
\hline Hari ke-8 & Perlakuan & 6 & $871,00 \pm 144,32$ \\
\hline & Kontrol & 6 & $809,00 \pm 244,20$ \\
\hline Hari ke-14 & Perlakuan & 6 & $612,00 \pm 154,46$ \\
\hline & Kontrol & 6 & $894,00 \pm 223,50$ \\
\hline & Perlakuan & 6 & $890,00 \pm 111,39$
\end{tabular}

Pada hari ke-8: Penurunan kadar serum ALP pada kelompok Perlakuan: $30 \%$. 


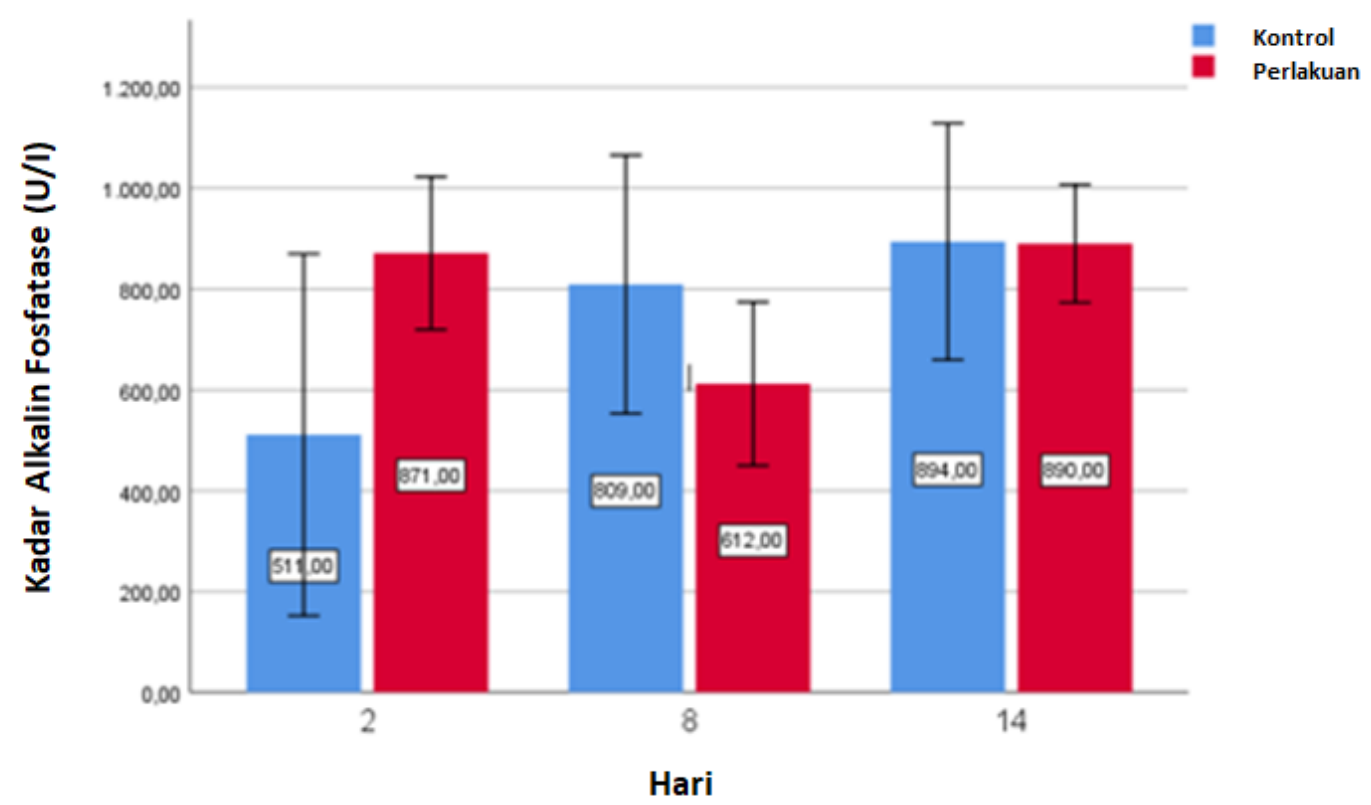

Gambar 1. Perbandingan Antara Kadar Serum ALP Pada Kelompok Yang Berbeda

Berdasarkan gambar 1, diagram batang menunjukkan bahwa rata-rata kadar serum ALP menurun saat hari ke-8 pada kelompok perlakuan.

Tabel 2. Uji Beda Kadar ALP Serum Antara Kelompok Kontrol Dan Perlakuan Pada Hari Ke-2, 8 Dan 14

\begin{tabular}{cc}
\hline Kelompok & Sig. \\
\hline Day 2 & $0,051^{*}$ \\
\hline Day 8 & $0,126^{*}$ \\
\hline Day 14 & $0,969 *$ \\
\hline *Independence T-test $(\mathrm{p}<0,05)$
\end{tabular}

Data dari tabel 2 menunjukkan bahwa tidak terdapat perbedaan yang signifikan antara kelompok kontrol dan kelompok perlakuan pada hari ke-2 $(\mathrm{p}=0,051)$, hari ke-8 $(\mathrm{p}=0,126)$, dan hari ke-14 $(\mathrm{p}=0,969)$.

Kemudian untuk mengetahui apakah ada perbedaan yang signifikan antara kelompok kontrol pada hari ke-2 dan hari ke-8, kelompok kontrol pada hari ke-8 dan hari ke 14, dan kelompok perlakuan pada hari ke-8 dan hari ke-14 digunakan uji-t berpasangan. Perbedaan dianggap signifikan jika p-value $<0,05$ [14-16].

Tabel 3. Uji Perbedaan Kadar ALP Serum Antara Hari Ke-2 Dan Hari Ke-8, Hari Ke-8 Dan Ke14, Serta Hari Ke-2 Dan Ke-14 Baik Kelompok Kontrol Maupun Kelompok Perlakuan

\begin{tabular}{cc}
\hline Group & Sig. \\
\hline Kontrol Hari ke-2 dan 8 & $0,023^{*}$ \\
\hline Kontrol Hari ke-8 dan 14 & $0,587 *$ \\
\hline Kontrol Hari ke-2 dan 14 & $0,097 *$ \\
\hline Perlakuan Hari ke-2 dan 8 & $0,077^{*}$ \\
\hline Perlakuan Hari ke-8 dan 14 & $0,004 *$ \\
\hline Perlakuan Hari ke-2 dan 14 & $0,825 *$ \\
\hline & $*$ Paired T-test $(\mathrm{p}<0,05)$
\end{tabular}

Mengacu dari tabel 3, perbedaan bermakna hanya ditemukan antara kadar ALP serum pada kelompok kontrol pada hari ke-2 dan hari ke-8 $(\mathrm{p}=0,023)$, dan antara kelompok perlakuan pada hari ke-8 dan hari ke-14 ( $\mathrm{p}=0,004)$.

\section{Laju Kontraktur Luka}


Tabel 4. Rata-Rata Tingkat Kontraktur Luka

\begin{tabular}{ccc}
\hline \multirow{2}{*}{ Kontrol } & \multicolumn{2}{c}{ Mean } \\
\cline { 2 - 3 } & Kontrol & Perlakuan \\
\hline Hari ke-5 & 72,594 & 83,84 \\
\hline Hari ke-8 & 69,211 & 74,28 \\
\hline Hari ke-12 & 66,788 & 64,6 \\
\hline Hari ke-15 & 63,131 & 60,76 \\
\hline Hari ke-18 & 59,703 & 50,2 \\
\hline Hari ke-21 & 57,829 & 45,2 \\
\hline
\end{tabular}

Peningkatan kontraktur luka saat hari ke-5 mencapai $14 \%$ pada kelompok perlakuan apabila dibandingkan dengan kelompok kontrol.

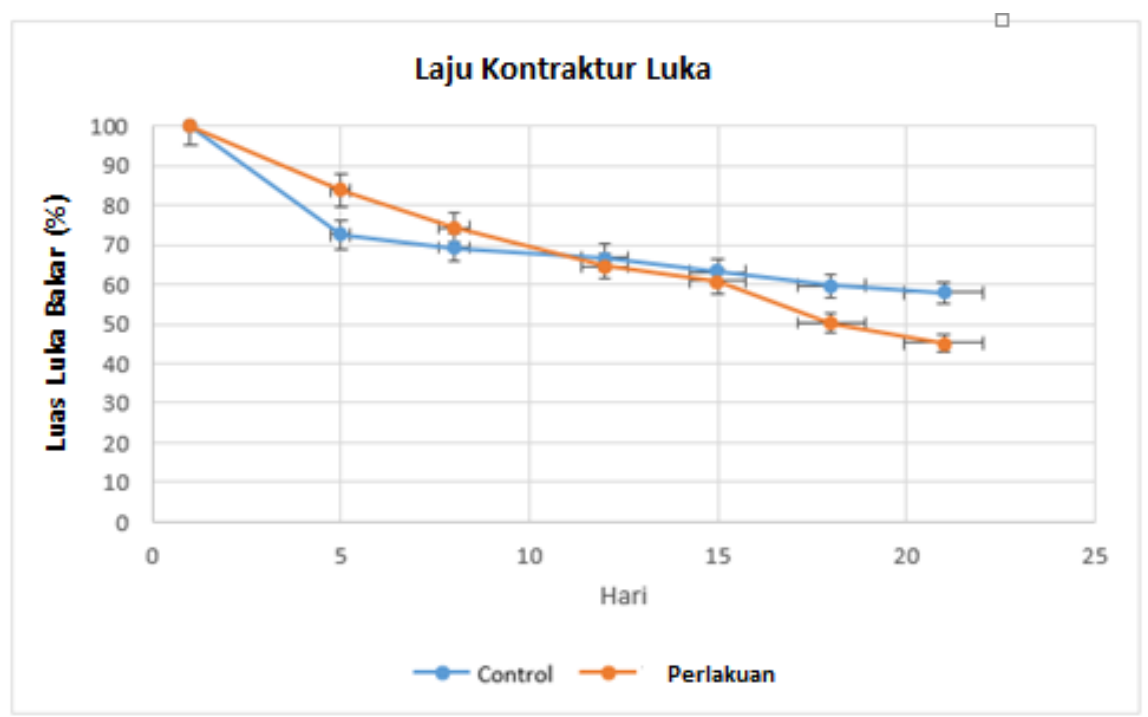

Gambar 2. Laju Kontraktur Luka

Berdasarkan Gambar 2, kecenderungan menurun terlihat pada luas luka bakar pada kelompok kontrol dan perlakuan selama 21 hari. Secara keseluruhan, selama 21 hari, gradien tingkat kontraktur kelompok perlakuan lebih curam daripada kelompok kontrol. Namun, diamati bahwa tingkat kontraktur kelompok kontrol lebih cepat daripada kelompok perlakuan selama sepuluh hari pertama.

Tabel 5. Uji Normalitas Area Luka Bakar ( Saphiro-Wilk )

\begin{tabular}{ccc}
\hline Kelompok & \multicolumn{2}{c}{ Sig. } \\
\cline { 2 - 3 } & Kontrol & Perlakuan \\
\hline Hari ke 5 & $0,252^{*}$ & $0,236^{*}$ \\
\hline Hari ke 8 & $0,265^{*}$ & $0,063^{*}$ \\
\hline Hari ke 12 & $0,222^{*}$ & $0,067^{*}$ \\
\hline Hari ke 15 & 0,033 & $0,592^{*}$ \\
\hline Hari ke 18 & $0,113^{*}$ & $0,903^{*}$ \\
\hline Hari ke 21 & 0,031 & $0,155^{*}$ \\
\hline & ${ }^{*} p>0,05$ &
\end{tabular}

Uji normalitas Saphiro-Wilk dilakukan pada luas luka bakar pada kelompok kontrol dan kelompok perlakuan pada hari ke-5, 8, 12, 15, 18 dan 21. Hasil pengujian menunjukkan bahwa data yang berdistribusi normal adalah kelompok kontrol pada hari $5(\mathrm{p}=0,252)$, kelompok kontrol pada hari ke-8 ( $\mathrm{p}=0,265)$, kelompok kontrol pada hari ke-12 $(\mathrm{p}=0,222)$, kelompok kontrol pada hari ke$18(\mathrm{p}=0,113)$, kelompok perlakuan pada hari ke-5 $(\mathrm{p}=0,236)$, kelompok perlakuan hari ke-8 $(\mathrm{p}=0,063)$, kelompok perlakuan hari ke-12 $(\mathrm{p}=0,067)$, kelompok perlakuan hari ke-15 $(\mathrm{p}=0,592)$, kelompok perlakuan hari ke-18 ( $\mathrm{p}=0,903)$ dan kelompok perlakuan hari ke-21 $(\mathrm{p}=0,155)$. Sedangkan, data kelompok kontrol pada hari ke-15 $(\mathrm{p}=0,033)$ dan kelompok kontrol pada hari ke$21(\mathrm{p}=0,031)$ menunjukkan distribusi yang tidak normal. 
Selanjutnya dilakukan uji independent t-test untuk mengetahui apakah ada perbedaan yang signifikan antara kelompok kontrol dan kelompok perlakuan pada hari ke-5, 8, 12 dan 18, dimana perbedaan tersebut dianggap signifikan jika $p$-value $<0,05$. Di sisi lain, uji Mann-Whitney [16] dilakukan untuk menemukan perbedaan yang signifikan antara kelompok kontrol dan kelompok perlakuan pada hari ke-15 dan hari ke-21.

Tabel 6. Uji Beda Luas Luka Bakar Kelompok Kontrol Dan Kelompok Perlakuan Pada Hari Ke-5, $8,12,15,18$ dan 21

\begin{tabular}{cc}
\hline Kelompok & Sig. \\
\hline Hari ke 5 & $0,272^{*}$ \\
\hline Hari ke 8 & $0,552^{*}$ \\
\hline Hari ke 12 & $0,758^{*}$ \\
\hline Hari ke 15 & $0,924^{* *}$ \\
\hline Hari ke 18 & $0,345^{*}$ \\
\hline Hari ke 21 & $0,412^{* *}$ \\
\hline *Independent T-test $(\mathrm{p}<0,05)$ \\
$* *$ Mann Whitney Test $(\mathrm{p}<0,05)$
\end{tabular}

Mengacu dari tabel 6 , tidak ada perbedaan yang signifikan antara angka kontraktur kelompok kontrol dan kelompok perlakuan pada semua hari.

\section{Analisis Alkalin Fosfatase}

Data yang diperoleh menunjukkan bahwa tidak terdapat perbedaan yang bermakna antara kadar ALP serum pada kelompok kontrol dan kelompok perlakuan pada hari ke-2, 8 dan 14. Hal ini mungkin disebabkan karena kurangnya variasi dosis yang digunakan dalam percobaan karena dosis yang digunakan hanya $300 \mathrm{mg} / \mathrm{KgBB}$. Akibatnya, dosis optimal untuk percobaan ini tidak dapat ditentukan. Pemilihan dosis didasarkan pada beberapa penelitian sebelumnya terkait dengan Ashitaba. Dalam penelitian sebelumnya yang dilakukan di Atsugi Breeding Center di Jepang, dosis oral $300 \mathrm{mg} / \mathrm{KgBB}$ terbukti sebagai dosis efek non-genotoksik [11]. Selain itu beberapa penelitian lain yang dilakukan menggunakan dosis antara $100-500 \mathrm{mg} / \mathrm{kgBB}$. Namun, belum ada penelitian yang membuktikan dosis optimal ekstrak tanaman Ashitaba dan hubungannya dengan luka bakar.

Selain itu, data menunjukkan bahwa ada peningkatan yang signifikan rata-rata tingkat ALP pada kelompok kontrol antara hari ke-2 dan hari ke-8 tetapi tidak ada peningkatan yang signifikan yang diamati antara hari ke-2 dan ke-14 serta antara hari ke-8 dan ke-14. Hal ini sesuai dengan penelitian yang dilakukan oleh Usha Adiga et al pada tahun 2015 [17] yang menyatakan bahwa kadar serum ALP meningkat pada 7 hari pertama sejak paparan air mendidih tetapi menurun 21-35 hari kemudian. Ini menjelaskan fakta bahwa ada peningkatan yang signifikan pada hari ke-8 tetapi tingkat peningkatannya melambat 2 minggu kemudian. Hal ini juga sesuai dengan proses penyembuhan luka yang terbagi menjadi 3 fase yaitu inflamasi, proliferasi dan remodelling. Fase inflamasi terjadi dalam 24-48 jam pertama [18]. Fase proliferasi melibatkan proses angiogenesis, fibroplasia dan reepitelisasi, yang terjadi 2-14 hari kemudian. Sesuai dengan jurnal oleh Denise Hawkins et al pada tahun 2007 [20]. Kadar ALP tertinggi pada jaringan granulasi dan fibroblas ditemukan pada fase proliferasi. Akibatnya, terjadi peningkatan yang signifikan pada hari ke-8 dan terjadi peningkatan pada hari ke-14. Fase remodeling terjadi 2-3 minggu setelahnya sehingga peningkatan kadar serum ALP melambat pada hari ke-14 [21].

Hasil yang diperoleh juga menunjukkan bahwa terdapat penurunan kadar ALP serum yang tidak signifikan antara hari ke-2 dan ke-8. Hal ini menunjukkan bahwa ekstrak tanaman Ashitaba mungkin memiliki beberapa manfaat dalam mengobati luka bakar tetapi manfaatnya kurang signifikan secara statistik karena kurang optimalnya pengobatan dosis yang digunakan. Sebaliknya, kadar serum ALP meningkat secara signifikan pada hari ke-14 yang menunjukkan progresi kerusakan jaringan. Hal ini mungkin disebabkan oleh volume darah yang diambil terlalu banyak karena dilakukan setiap minggu selama percobaan. Volume darah yang diambil dalam percobaan ini adalah $10 \%$ dari total volume darah yang mengikuti pedoman oleh National Center for the Replacement Refinement \& Reduction of Animals in Research. Namun, jurnal lain dari Jackson Laboratory pada tahun 2005 [22], menyatakan bahwa volume maksimum darah yang diambil tidak boleh melebihi $7,5 \%$ dari total volume darah jika pengambilan darah dilakukan setiap minggu. 
Sedangkan volume maksimal darah yang diambil tidak boleh melebihi $10 \%$ dari total volume darah jika darah diambil setiap dua minggu. Menurut jurnal ini, kehilangan darah dapat mengganggu stabilitas fisiologis tikus dan ambang batas maksimum volume darah yang diambil menurun pada tikus dengan meningkatnya tingkat stres yang meliputi luka bakar. Kehilangan darah yang berlebihan dapat menyebabkan syok hipovolemik terutama pada tikus yang terkena luka bakar. Hal ini akan mempengaruhi proses penyembuhan luka.

Selain itu, terjadinya infeksi dan sepsis dapat menjadi faktor pendukung hasil percobaan. Paparan luka bakar ke lingkungan yang terkontaminasi dan penularan langsung dari peneliti dapat menyebabkan invasi bakteri berbahaya dan memperlambat proses penyembuhan luka [23]. Hal ini dapat diamati pada percobaan ini yang dibuktikan dengan adanya nanah yang terlihat pada beberapa luka bakar. Infeksi dan sepsis juga dapat menyebabkan kerusakan sel lebih lanjut yang meningkatkan kadar serum ALP sehingga mengubah hasil percobaan [17].

\section{Analisis Laju Kontraktur Luka}

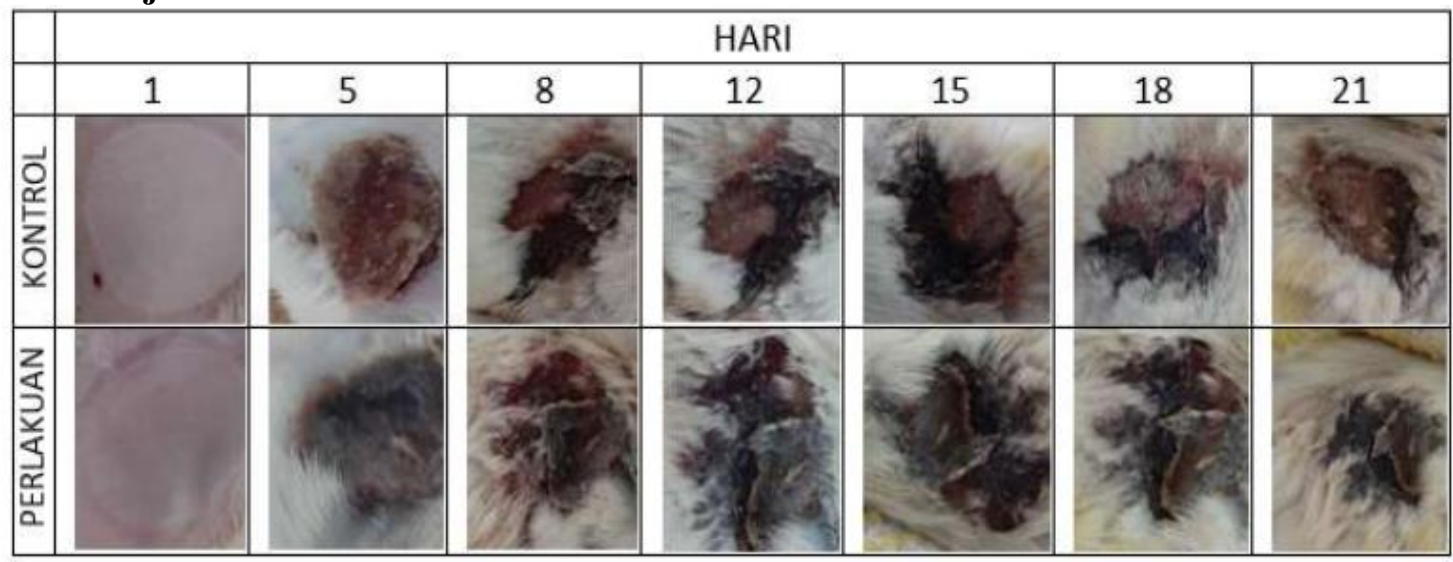

Gambar 3. Pengamatan Makroskopik Lesi Luka Bakar Selama 21 Hari

Data menunjukkan bahwa luas luka bakar pada kelompok kontrol dan kelompok perlakuan berkontraksi dan mengecil selama 21 hari pengamatan. Hal ini sesuai dengan teori proses penyembuhan luka yang terbagi menjadi 3 fase yaitu inflamasi, proliferasi dan remodeling. Fase inflamasi biasanya terjadi dalam 24-48 jam pertama [18]. Fase proliferasi meliputi angiogenesis, fibroplasia dan reepithelialisaton, yang terjadi dalam 2-14 hari ke depan [19]. Terakhir, fase remodeling terjadi 2-3 minggu hingga 1 tahun atau lebih, di mana luka mulai berkontraksi [21]. Namun, tidak ada perbedaan signifikan yang ditemukan antara area luka bakar pada kelompok kontrol dan kelompok perlakuan dalam semua hari selama 21 hari. Ini mungkin karena dosis yang digunakan tidak optimal untuk menghasilkan hasil yang signifikan. Dosis Ashitaba yang digunakan hanya berdasarkan penelitian sebelumnya yang tidak spesifik untuk kasus luka bakar [11]. Berbagai dosis diperlukan dalam percobaan masa depan untuk memastikan apakah hasil yang signifikan dapat diperoleh.

\section{CONCLUSION}

Kesimpulannya, ekstrak tanaman Ashitaba tidak terbukti secara signifikan menurunkan kadar ALP serum, meningkatkan tingkat kontraktur dan mempercepat proses penyembuhan luka bakar. Namun, ada sedikit peningkatan tingkat kontraktur pada kelompok perlakuan dibandingkan dengan kelompok kontrol. Selain itu, terdapat penurunan kadar ALP pada kelompok perlakuan dibandingkan dengan kelompok kontrol pada hari ke-8. Penelitian lebih lanjut terutama mengenai variasi dosis untuk menentukan dosis optimal perlu dilakukan untuk memastikan efektivitas Ashitaba dalam mengobati luka bakar. Tes tambahan seperti pemeriksaan histopatologi dan indikator laboratorium seperti albumin, malondialdehid, glutathione dan superoksida dismutase juga dapat dimasukkan dalam penelitian terkait di masa mendatang.

\section{Ucapan Terima kasih:}

Karya tulis ini didukung oleh Departemen Biologi dan Biokimia, Fakultas Kedokteran 
Universitas Diponegoro.

\section{REFERENCES}

[1] Keputusan Menteri Kesehatan Republik Indonesia Nomor HK.01.07/MENKES/555/201 9 Tentang Pedoman Nasional Pelayanan Kedokteran Tata Laksana Luka Bakar

[2] Garcia-Espinoza JA, Aguilar- Aragon VB, Ortiz-Villalobos EH, Garcia-Manzano RA, Antonio BA. Burns: Definition, Classification, Pathophysiology and Initial Approach, International Journal of General Medicine, 2017; 5:5, https://doi.org/10.4172/23275146.1000298

[3] Tiwari VK. Burn wound: How it differs from other wounds?, Indian Journal of Plastic Surgery, 2012;45(2):364-373, https://doi.org/10.4103/0970- 0358.101319

[4] Sehirli O, Sener E, Sener G, Cetinel S, Erzik C, Yeğen BC. Ghrelin improves burn- induced multiple organ injury by depressing neutrophil infiltration and the release of pro-inflammatory cytokines, Peptides, 2008; 29:12. 31-40, https://doi.org/10.1016/j.peptides.2008.02.012

[5] Wang S, Huang Q, Guo J, Local thermal injury induces general endothelial cell contraction through p38 MAP kinase activation, Acta Pathologica, Microbiologica, et Immunologica Scandinavica, 2014;122:832-41, https://doi.org/10.1111/apm.12226

[6] Huang QB, Relationship between the endothelial barrier and vascular permeability after burns and its mechanism, Zhonghua Shao Shang Za Zhi, 2007; 23: 324-6. https://pubmed.ncbi.nlm.nih.gov/18396754/

[7] Cotran RS, Abbas AK, Fausto N, Robbins SL, Kumar V, Robbins \& Cotran: Patologia - Bases Patológicas das Doenças, 7. ed. Rio de Janeiro: Elsevier; 2005. 1592 p

[8] Sarkar SD, Nahar L, Natural medicine: the genus Angelica, Current Medicinal Chemistry, 2004; 11: 1479-1500, https://doi.org/10.2174/0929867043365189

[9] Caesar LK, Cech NB. A Review of the Medicinal Uses and Pharmacology of Ashitaba, Planta Medica, 2016 ;82(14):1236-45. https://doi.org/10.1055/s-0042-110496

[10] Hisatome T, Wachi Y, Yamamoto Y, Ebihara A, Ishiyama A, Miyazaki H, Promotion of Endothelial Wound Healing by the Chalcones 4-hydroxyderricin and Xanthoangelol, and the Molecular Mechanism of This Effect, Journal of Sustainable Agriculture, 2017; 12: 25-33, https://doi.org/ 10.1262/jrd.2018-141

[11] Maronpot RR, Toxicological assessment of Ashitaba Chalcone, Food Chemical Toxicology, 2015; 77: 111-19, https://doi.org/ 10.1016/j.fct.2014.12.021

[12] Tietz NW, Rinker AD, Shaw LM. IFCC methods for the measurement of catalytic concentration of enzymes, Part 5, IFCC method for alkaline phosphatase, Journal of Clinical Chemistry and Clinical Biochemistry, 1983;21:731-748.

[13] Zhang XG, Li XM, Zhou XX, Wang Y, Lai WY, Liu Y, et al, The Wound Healing Effect of Callicarpa Nudiflora in Scalded Rats, Evidence Based Complement Alternative Medicine. 2019; 2019: 1-8, https://pubmed.ncbi.nlm.nih.gov/6655448/

[14] Ghasemi A, Zahediasl S, Normality tests for statistical analysis: a guide for non-statisticians, International Journal of Endocrinol and Metabolism, 2012; 10(2): 486-489, https://doi.org/10.5812/ijem.3505

[15] Kim TK. T test as a parametric statistic. Korean Journal of Anesthesiology, 2015; 68(6): 540546, https://doi.org/10.4097/kjae.2015.68.6.540

[16] Fay MP, Proschan MA. Wilcoxon-Mann-Whitney or t-test? On assumptions for hypothesis tests and multiple interpretations of decision rules, Statistics Survey. 2010; 4:1-39, https://doi.org/10.1214/09-SS051

[17] Adiga U, Adiga S, Biochemical Changes in Burns, International Journal of Research Studies in Biosciences, 2015; 3(7): 88-91, https://doi.org/10.1136/pgmj.48.557.144

[18] Eming SA, Krieg T, Davidson JM. Inflammation in wound repair molecular and cellular mechanisms, Journal of Investigative Dermatology, 2007; 127: 514-525. https://doi.org/10.1038/sj.jid.5700701

[19] Li J, Chen J, Kirsner R, Pathophisiology of acute wound healing, Clinics in Dermatology, 2007;25:9-18, https://doi.org/10.1016/j.clindermatol.2006.09.007

[20] Hawkins, Denise, and Heidi Abrahamse, "How Should an Increase in Alkaline Phosphatase 
Activity Be Interpreted?" Laser Chemistry, 2007.1-10, https://doi.org/10.1155/2007/49608

[21] Gonzalez AC, Costa TF, Andrade ZA, Medrado AR, Wound healing - A literature review, The journal Brazilian Annals of Dermatology, 2016; 91(5): 614-20, https://doi.org/10.1590/abd1806-4841.20164741

[22] The Jackson Laboratory, How Much Blood Can I Take From A Mouse Without Endangering Its Health? eNews, 2005, https://www.jax.org/news-and-insights

[23] Church D, Elsayed S, Reid O, Winston B, Lindsay R, Burn Wound Infections, Clinical Microbiology Reviews, 2006; 19(2), https://doi.org/10.1128/CMR.19.2.403-434.2006. 